Physical Signs

\title{
Graves' disease presenting as pyrexia of unknown origin
}

\author{
Yechiel Shaked, ${ }^{1}$ Yecheskel Samra ${ }^{1}$ and S. Tsila Zwas ${ }^{2}$ \\ ${ }^{1}$ Rusinow Department of Internal Medicine $C$ and the ${ }^{2}$ Institute of Nuclear Medicine, the Chaim Sheba \\ Medical Center, Tel-Hashomer and Sackler School of Medicine, Tel-Aviv University, Israel
}

\begin{abstract}
Summary: Fever is a common clinical manifestation of inflammatory processes of the thyroid and thyroid crisis. On the other hand, fever alone as a presenting symptom of thyrotoxicosis, without other manifestations, is extremely rare. A female patient is described in whom fever persisted for two months prior to hospitalization, but without clinical symptoms or signs to lead to suspicion of thyroid disease. After exhaustive investigation it was found that the patient was suffering from hyperthyroidism. Fever disappeared gradually on antithyroid therapy, recurred when the drugs were withdrawn for a rechallenge trial, and cleared up again after renewal. Four other cases of persistent fever as a presenting symptom of hyperthyroidism were found on a review of previous publications. Thyrotoxicosis should, therefore, be included in the differential diagnosis of pyrexia of unknown origin.
\end{abstract}

\section{Introduction}

Fever as an indicator of disease has always been and remains a clinical symptom of prime importance. ${ }^{1-3}$ There is no doubt that a number of inflammatory, neoplastic and other diseases may present with fever alone. Fever may also accompany a number of endocrine diseases. ${ }^{4-6}$ The first article dealing with this problem appeared in $1948^{7}$ and its rarity as a presenting sign was emphasized at that time.

Diseases of the thyroid which are manifested by fever alone are considered to be extremely rare, although fever is one of the symptoms typical of inflammatory processes in the gland, such as subacute thyroiditis ${ }^{8.9}$ and thyroid crisis. ${ }^{10,11}$ This article describes a patient with persistent fever of up to $38.7^{\circ} \mathrm{C}$. It became clear after an extensive investigation of her pyrexia of unknown origin (PUO) that the fever was due to a non-inflammatory thyrotoxic disorder.

\section{Case report}

A 57 year old female had open mitral commis-

Correspondence: Y. Shaked, M.D.

Accepted: 20 October 1987 surotomy at the age of 32. She was hospitalized because of fever above $38^{\circ} \mathrm{C}$ accompanied by weakness, fatigue and night sweats for two months prior to admission. Physical examination showed good general condition. Her body weight remained unchanged during the 6 weeks of hospital observation. Her temperature was between $37.5^{\circ} \mathrm{C}$ (morning) and $38.7^{\circ} \mathrm{C}$ (evening). The thyroid gland was somewhat diffusely enlarged but not tender. There were no signs of thyrotoxicosis. She had atrial fibrillation and signs of mitral incompetence. The liver, spleen and lymph nodes were not palpable, and there were no peripheral manifestations of subacute bacterial endocarditis or signs of heart failure. Gynaecological examination was normal. Chest X-ray showed clear lung fields. Echocardiography showed mild mitral insufficiency, mitral stenosis and an enlarged left atrium, with no signs of vegetations or a space-occupying lesion.

Laboratory tests revealed normal haematological and biochemical findings. Widal, Weil-Felix, brucella and Q-fever agglutination tests, cold agglutinins, mono-slide, latex test and antinuclear factor, and serological tests for cytomegalovirus and Epstein-Barr virus were all negative. Blood cultures (aerobic, anaerobic and fungi) were sterile. Urine, faeces and sputum cultures were negative.

(C) The Fellowship of Postgraduate Medicine 1988 
Dental examinations, including panoramic X-ray, intravenous pyelography, barium enema, barium meal, ultrasound and computed tomographic examinations of the abdomen and pelvis were normal. Liver and bone radionuclide scans, $\mathrm{Ga}^{67}$ radionuclide whole body scan, including the region of the thyroid gland, were all normal. Thyroid gland function tests, indicating a thyrotoxic state, are shown in Table I. Serological tests for antithyroid microsomal antibodies and anti-TBG (thyroxine-binding globulin) antibodies were negative. On technetium $-99 \mathrm{~m}$ pertechnetate thyroid scan, the right lobe and isthmus of the thyroid gland appeared somewhat enlarged, with homogeneous distribution of the radionuclide (Figure 1).

Cardiac medication was continued as betore (dipyridamole, frusemide and digoxin). Following a 3-week period of observation, during which the fever continued and a diagnosis of hyperthroidism was established, antithyroid treatment was initiated with lugol solution, 5 drops, 3 times daily, and methimazole, $40 \mathrm{mg}$ daily. The fever started to lyse after 10 days. The patient was discharged on methimazole.

Two weeks later, on reexamination, the patient remained afebrile and in excellent condition. Thyroid function tests returned to normal values. Two months after its initiation, the antithyroidal treatment was discontinued. After 5 days, the fever rose again to $38^{\circ} \mathrm{C}$ at night and was accompanied by general malaise. The $T_{4}$ value rose to over $18 \mu \mathrm{g} / \mathrm{dl}$. Methimazole therapy was resumed and the patient became euthyroid again within 2 weeks, was afebrile and felt well.

\section{Discussion}

A large group of endocrine and metabolic diseases are mentioned among the less common causes of PUO, ${ }^{4,5}$ including thyroiditis, hyperthyroidism,

Table I Thyroid gland function tests

Total serum thyroxine

$211.5-224.5 \mathrm{nmol} / 1$

(normal: $60.6-154.8 \mathrm{nmol} / \mathrm{l}$ )

Triiodothyronine resin uptake $66-69 \%$

(normal: $40-55 \%$ )

Free thyroxine index

$278.6-287.7 \mathrm{nmol} / 1$

(normal: $51.6-167.7 \mathrm{nmol} / \mathrm{l}$ )

Triiodothyronine radioimmunoassay

$3.8 \mathrm{nmol} / 1$

(normal: $1.47-3.0 \mathrm{nmol} / \mathrm{l}$ )

Thyroid stimulating hormone radioimmunoassay $1.2 \mathrm{U} / \mathrm{ml}$

(normal: $0.5-4.0 \mathrm{U} / \mathrm{ml}$ )
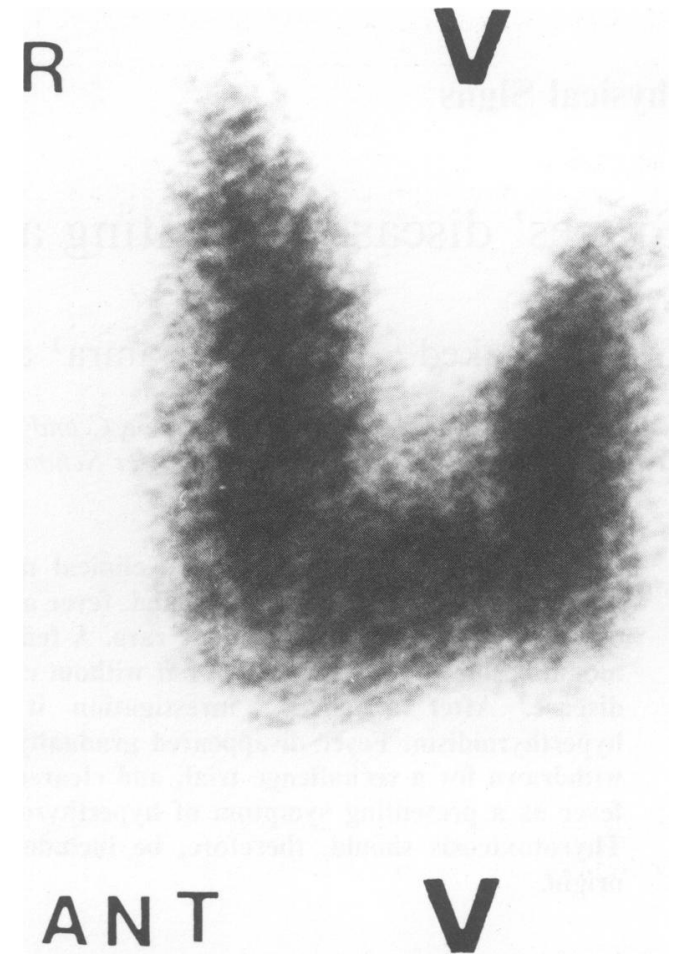

Figure 1 Anterior view thyroid scan (with technetium99 m-pertechnetate) shows a mildly enlarged gland mainly in the right lobe with homogeneous distribution of the radioactivity, except for some lobularity in the widened right lower lobe region. (Sternal notch and thyroid cartilage are marked by $\mathrm{V}$ signs).

Addison's disease, Fabry's disease, hyperlipidaemia, phaeochromocytoma, primary hyperparathyroidism, nephrogenic diabetes insipidus in the newborn and hypoglycaemia. In older textbooks, hyperthyroidism is often mentioned as accompanied by fever between $37.2-38^{\circ} \mathrm{C} .{ }^{12}$ Hyperpyrexia above $38.4^{\circ} \mathrm{C}$ is a common sign of thyroid crisis. In the latter, tachycardia, severe agitation, profuse sweating, nausea and vomiting are frequent and even death may occur. ${ }^{10,11}$ In more recent articles ${ }^{13}$ and textbooks, ${ }^{14}$ fever is not mentioned as a manifestation of thyrotoxicosis. Hyperthyroidism presenting primarily as persistent fever is extremely rare. In these cases, a long-lasting fever is not accompanied by other clinical manifestations of thyrotoxicosis. In extensive reviews on PUO, ${ }^{1-20}$ with a single exception, ${ }^{21}$ hyperthyroidism is not listed as a cause.

The four previously published cases of persistent fever caused by hyperthyroidism, ${ }^{4,6,21}$ as well as this case, are summarized in Table II. In no case 
Table II Cases of hyperthyroidism presenting as pyrexia of unknown origin

\begin{tabular}{|c|c|c|c|c|c|c|c|c|c|c|}
\hline $\begin{array}{c}\text { Case no. } \\
\text { (ref.) }\end{array}$ & $\begin{array}{l}\text { Age in } \\
\text { years }\end{array}$ & Sex & $\begin{array}{c}\text { Duration } \\
\text { of } \\
\text { pyrexia* }\end{array}$ & $\begin{array}{l}\text { Max. } \\
\text { temp. } \\
\left({ }^{\circ} \mathrm{C}\right)\end{array}$ & $\begin{array}{c}\text { Other } \\
\text { symptoms }\end{array}$ & $\begin{array}{l}\text { Physical } \\
\text { findings }\end{array}$ & $\begin{array}{l}\text { Results of } \\
\text { thyroid } \\
\text { function } \\
\text { tests }\end{array}$ & Therapy & Response & $\begin{array}{c}\text { Final } \\
\text { Diagnosis }\end{array}$ \\
\hline $1(21)$ & NS & NS & 1 & 38.9 & $\begin{array}{l}\text { Chills } \\
\text { Arthralgia } \\
\text { Night sweats } \\
\text { Nausea } \\
\text { Weight loss }\end{array}$ & $\begin{array}{l}\text { Lympha- } \\
\text { denopathy } \\
\text { Hepato- } \\
\text { splenomegaly }\end{array}$ & NS & NS & NS & NS \\
\hline $2(4)$ & NS & $\mathbf{F}$ & Several & NS & Weight loss & $\begin{array}{l}\text { Persistent } \\
\text { tachycardia }\end{array}$ & NS & NS & NS & $\begin{array}{l}\text { Graves' } \\
\text { disease }\end{array}$ \\
\hline $3(6)$ & 58 & $\mathrm{~F}$ & 1 & 38.2 & $\begin{array}{l}\text { Night sweats } \\
\text { Fatigue } \\
\text { Myalgia }\end{array}$ & None & $\mathrm{T}_{4} 18.4 \mathrm{mcg} / \mathrm{dl}$ & $I^{132}$ & $\begin{array}{l}\text { Afebrile } \\
\text { on } \\
\text { discharge }\end{array}$ & $\begin{array}{l}\text { Graves' } \\
\text { disease }\end{array}$ \\
\hline $4(6)$ & 48 & $\mathbf{M}$ & 4 & 37.8 & Night sweats & Exophthalmus & $\mathrm{T}_{3} 5.00 \mathrm{ng} / \mathrm{dl}$ & PTU $†$ & $\begin{array}{l}\text { Afebrile } \\
\text { within } \\
2 \text { months }\end{array}$ & $T_{3}$-Toxicosis \\
\hline 5 (ours) & 57 & $\mathbf{M}$ & 2 & 38.7 & $\begin{array}{l}\text { Night sweats } \\
\text { Fatigue }\end{array}$ & $\begin{array}{l}\text { Slight } \\
\text { thyroid } \\
\text { enlargement }\end{array}$ & $\begin{array}{l}\mathrm{T}_{4} 211 \mathrm{nmol} / 1 \\
\mathrm{~T}_{3} 3.8 \mathrm{nmol} / 1\end{array}$ & $\begin{array}{l}\text { Lugol+ } \\
\text { Methi- } \\
\text { mazole }\end{array}$ & $\begin{array}{l}\text { Afebrile } \\
3 \text { weeks }\end{array}$ & $\begin{array}{l}\text { Graves' } \\
\text { disease }\end{array}$ \\
\hline
\end{tabular}

*In months prior to admission; NS - not stated; $\uparrow \mathrm{PTU}$ - propylthiouracil; $\mathrm{T}_{4}$ - thyroxine; $\mathrm{T}_{3}$ - triiodothyronine.

were there clinical symptoms which would lead to suspicion of thyroid disease, although night sweats were present in each case, loss of weight occurred in two cases and exophthalmos in one. Sub-febrile temperature (around $37.5^{\circ} \mathrm{C}$ ) is often found in typical cases of thyrotoxicosis, together with other clinical manifestations, but these are usually so prominent that the sub-febrile temperature can easily overlooked. In all cases (Table II), and in particular in our own, fever was the presenting symptom and the other manifestations of thyrotoxicosis were absent, or so mild that they were ignored.

Unexpected tachycardia should normally direct attention to thyrotoxic states, ${ }^{4}$ but the absence of tachycardia does not eliminate this possibility,

\section{References}

1. Phair, J.P. Fever (Editorial). Arch Intern Med 1979, 131: 1219.

2. Musher, D.M., Fainstein, V., Young, E.J. \& Pruett, T.L. Fever patterns. Arch Intern Med 1979, 131: 12251228.

3. Adnan, R.P., Fauci, A.S., Dale, D.C. et al. Factitious fever and self-induced infection: a report on 32 cases and review of the literature. Ann Intern Med 1979, 90: 230-242. especially when the patient receives various medications which may slow the pulse. It is said that thyrotoxicosis should be suspected if digitalis does not slow the pulse in atrial fibrillation, but this was not the case in our patient.

The pathogenesis of fever in thyrotoxicosis is not well understood and various theories are presented. Discussion on this point is beyond the scope of this paper and the reader is referred to the listed articles. ${ }^{22-24}$.

In the light of the above, it should be concluded that fever may be the only, or at least the most prominent clinical manifestation of thyrotoxicosis. We feel, therefore, that thyrotoxicosis should be included in the list of causes of pyrexia of unknown origin.
4. Buckley, R.M. Miscellaneous and unusual causes of FUO. In: Murray, H.W. (ed) FUO: Fever of Undetermined Origin. Futura, London, 1983, pp 109122.

5. PEO - Pyrexia of endocrine origin (Editorial). Lancet 1979, ii: $236-237$.

6. Simon, H.B. \& Daniels, G.H. Hormonal hyperthermia: endocrinologic causes of fever. Am J Med 1979, 66: 257-264. 
7. Neiburgs, H.E. \& Greenblatt, R.B. The role of the endocrine glands in body temperature regulation (Abstract). J Clin Endocrinol Metab 1948, 8: 622-623.

8. Levine, S.N. Current concepts on thyroiditis. Arch Intern Med 1983, 143: 1952-1956.

9. Dalovisio, J.R., Blonde, L., Cortez, L.M. \& Pankey, G.A. Subacute thyroiditis with increased serum alkaline phosphatase. Ann Intern Med 1978, 88: 505507.

10. Rawson, R.W. Hyperthyroidism. Disease-a-Month. The Year Book Publishers, Chicago, Apr 1955.

11. McArthur, J.W., Rawson, R.W., Means, J.H. \& Cope, O. Thyrotoxic crisis. JAMA 1947, 134: 864 874.

12. Beeson, P.B., Fever. In: MacBryde, C.M. (ed) Signs and Symptoms. J.B. Lippincott, Philadelphia, 1947.

13. Davis, P.J. \& Davis, F.B. Hyperthyroidism in patients over the age of 60 years: clinical features in 85 patients. Medicine (Baltimore) 1974, 55 161-181.

14. Ingbar, S.H. The thyroid gland; thyrotoxicosis. In: Williams Textbook of Endocrinology, 7th edition, 1985, pp 743-775.

15. Molavi, A. \& Weinstein, L. Persistent perplexing pyrexia: some comments on etiology and diagnosis. Med Clin North Am 1970, 54: 379-396.

16. Petersdorf, R.G. \& Beeson, P.B. Fever of unexplained origin: report of 100 cases. Medicine (Baltimore) 1961, 40: $1-30$.
17. Petterson, J. Fever of obscure origin: A follow-up investigation of 88 cases. Acta Med Scand 1962, 171: 575-583.

18. Gleckman, R. Crowley, M. \& Esposito, A. Fever of unknown origin: a view from the community hospital. Am J Med Sci 1977, 274: 21-25.

19. Larson, E.B., Featherstone, H.J. \& Petersdorf, R.G. Fever of undetermined origin: diagnosis and follow-up of 105 cases 1970-1980. Medicine (Baltimore) 1982, 61: 269-292.

20. Smith, T.W. Southern Internal Medicine Conference: fever of undetermined origin: not what it used to be. Am J Med Sci 1986, 292: 56-64.

21. Sheon, R.P. \& Van Ommen, R.A. Fever of obscure origin: diagnosis and treatment based on a series of sixty cases. Am J Med 1963, 34: 486-499.

22. Ismail-Beigi, F. \& Edelman, I.S. The mechanism of thyroid calorigenesis: role of active sodium transport. Proc Natl Acad Sci USA 1970, 67: 1071-1078.

23. Edelman, I.S. Thyroid thermogenesis. $N$ Engl J Med 1974, 290: 1303-1308.

24. Brookes, M.H., Sheldon, S.W., Bronsky, D. \& Sterling, K.J. Serum triiodothyronine concentration in thyroid storm. J Clin Endocrinol Metab 1975, 40: 339341. 